\title{
Computer-Based Multimedia Application in Education
}

\author{
Sun Lei \\ Xi'an International University, School of Foreign Languages, China, 710077 \\ 553107794@qq.com
}

\begin{abstract}
The use of Multimedia in teaching is of great significance and necessity and it has its own utilizing principle, yet not every teacher knows it, nor can they use them well. And the traditional teaching leaves little opportunity for nonprofessionals such as students to participate in curriculum planning. Consequently, these challenges necessitate a new approach to education. This approach should reflect the advancement of technology and telecommunication.
\end{abstract}

Index Terms - Computer, Multimedia, Technology, Education

\section{Introduction}

Nowadays, many universities and colleges in China have invested a large amount of money to set up multimedia equipment in classrooms to improve teaching and learning condition and effect. As a College English teacher, I found it has many advantages to use Multi-media technology in language teaching and learning. The evolution of technology in the classroom and the relationship between technology and change have encouraged teachers to explore new ways of using computers to communicate as well as to support and enhance instruction. Today's students live in a global-knowledge-based age: they deserve teachers whose practices embrace the best that technology can bring to learning [1]. In today's digital world, schools have the responsibility to produce a technology-literate learner prepared to excel in an everchanging information based society. The successful integration of technology into education, as a pedagogical tool, is critically connected to the level of teachers' technical skills and their confidence in applying those skills [2]. New technologies have helped create a culture for learning in which the learner enjoys enhanced interactivity and connections with others [3]. Rather than listen to a teacher repeat facts and theories, students discuss ideas and learn from one another.

To prepare all students for productive careers for the 21 th century, schools must change the way students are educated. One of the strongest arguments for increasing computer technology in school is that computers are essential for preparing students for the digital age [4].

\section{Related Terms}

\subsection{Technology}

It refers to electronic devices that increase productivity and access information. It is any hardware and/or software designed or available to access and process information directly or in distance. The word computer technology in this study is referring; but is not limited to, specific software, computers; sound recorders, video recorders, scanners, digital cameras and other telecommunication devices.

\subsection{Multimedia}

It broadly defined as a variety of software and hardware devices developed for all users to access and process information using multiple formats of communication, such as audio, video, text, photos, graphics, and animation.

\subsection{Technology and multimedia integration}

It is the extent to which teachers use computer technology and multimedia in instruction. For the purpose of this study, Robinson's definition of the integration of computer technology into instruction was adopted. Robinson's definition includes the following four important aspects: (a) teachers and their students must have adequate computer access, (b) teachers must have the technical and computer skills to make use of appropriate hardware and software; (c) teachers must have the pedagogical skills appropriate for teaching with computers and multimedia, and (d) teachers must have the ability to organize and manage computer-based and/or multimedia-based classroom activities.

\section{Traditional Learning and Digital Learning environment}

Computer technology and multimedia have been among the most widely promoted tools for enhancing the teaching and learning process. Yet the current learning and teaching environment does not encourage effective integration of computer technology and multimedia. In this regard, the international society for technology in education states that we should incorporate new strategies to establish new learning environments for digital age. Table 1 summarizes its description of the characteristics of a traditional learning environment and the one needed for the digital age [5].

Table 1.Characteristics of traditional versus digital learning environments

\begin{tabular}{|l|l|}
\hline $\begin{array}{l}\text { Characteristics of Traditional } \\
\text { Learning Environments }\end{array}$ & $\begin{array}{l}\text { Characteristics of New Learning } \\
\text { Environments }\end{array}$ \\
\hline Teacher-centered instruction & Student-centered learning \\
\hline Single sense stimulation & Multisensory stimulation \\
\hline Single path progression & Multipath progression \\
\hline Single media & Multimedia \\
\hline Isolated work & Collaborative work \\
\hline Information delivery & Information exchange \\
\hline Passive learning & Active/exploratory/inquiry-based learning \\
\hline $\begin{array}{l}\text { Factual, knowledge-based } \\
\text { learning }\end{array}$ & $\begin{array}{l}\text { Critical thinking and informed decision- } \\
\text { making }\end{array}$ \\
\hline Reactive response & Proactive/planned action \\
\hline Isolated ,artificial context & Authentic, real-world context \\
\hline
\end{tabular}


A new paradigm of learning has been proposed and discussed by Tapscott. Tapscott states that the broadcast learning paradigm, which focuses on instruction, is facing eight shifts. Table 2 presents the shifts of the past learning paradigm (broadcast learning) to interactive learning paradigm (digital learning) [6].

Table 2.The shifts from broadcast learning paradigm to interactive learning paradigm

\begin{tabular}{|l|l|}
\hline Broadcast learning & Interactive learning \\
\hline Liner & Hypermedia learning \\
\hline Instruction & Construction/discovery \\
\hline Teacher-centered & Learner-centered \\
\hline Absorbing material & Learning how to learn \\
\hline School & Lifelong \\
\hline One-size-fits all & Customized \\
\hline School as torture & School as fun \\
\hline Teachers as transmitter & Teacher as facilitator \\
\hline
\end{tabular}

\section{Constructivist Learning Theory}

To offer a foundation for analyzing and understanding the best practices of teachers who successfully integrate computer technology in teaching, constructivist learning theory can be used in practical teaching.

As technology becomes more common in our society and school, research is necessary to discover meaningful approaches to enhancing student learning using that technology. For meaningful integration of technology to occur, teachers require not only access to technology, but also a new understanding of how and why to use the technology and multimedia.

Becker stated that technology integration shifts the way teachers instruct. Teachers who had used computers in their classrooms for several years moved toward a"more constructivist"teaching style: Their instruction involved longer projects; they gave students more chance for active, out-of-seat work; they used more interdisciplinary content; and they gave students more opportunity to review and revise their work. Teachers with more than several years of experience using instructional technology also had their students work in cooperative groups more frequently and were more reflective about their teaching goals [7].

Constructivist perspective is connected with teaching practices developed to assist learners to adapt and transform new information. From this new information the learners can build cognitive structures which will enable them to rethink prior ideas as they create bases of knowledge they can generate, organize, demonstrate and exhibit. Constructivist practices include considerations for authentic learning, active learning, intentional processes toward achieving cognitive objectives and reflective learning activities.

\section{Conclusion}

Education is facing a paradigm shift under the rapid development of information technology. Computer technology, multimedia, the Internet and world wide web are the driving forces for new forms of educational delivery. Yet the current integration of computer technology and multimedia in China do not meet the requirements of the digital age, Moving courses from the traditional classrooms to technology-based classrooms basically shifts the learning and the teaching paradigm.

\section{References}

[1] Gagne, R. (1985). The cognitive psychology of school learning. Boston: Little Brown Company.

[2] Becker, H. (1998). Running to catch a moving train: Schools and information technologies. Theory into Practice.

[3] Dick, W., Carey, L., \& Carey, J. (2001). The systematic design of instruction ( $5^{\text {th }}$ ed.). NY: Longman.

[4] Ary, D., Jacobs, L., \& Razavieh, A. (1996). Introduction to research in education (5th ed.). NY: Harcourt Brace College Publishers.

[5] Negroponte, N. (1995). Being digital. New York: Alfred A. Kopf, Inc

[6] Morrison, G., \& Lowther, D. (2002). Integrating computer technology into the classroom. Columbus, $\mathrm{OH}$ : Sage.

[7] Kent, T., \& McNergney, R. (1999). Will technology really change education? From blackboard to Web. Thousand Oaks, CA: Sage. 